\title{
The Effectiveness of The Method of Opening The Reed's Land Against Nutrient Removal
}

\author{
Aprisal $^{1}$, Bambang Istijono $^{2}$, Asmar $^{3}$, Ayu Seriosta $^{4}$ \\ \{aprisalunand@yahoo.co.id ${ }^{1}$,bistijono@yahoo.co.id $\left.{ }^{2}\right\}$ \\ Soil Science Department, Agriculture Faculty of Andalas University, Limau Manis, Padang, \\ Indonesia ${ }^{1}$, Engineering Faculty, Andalas University, Limau Manis, Padang, Indonesia ${ }^{2}$, Andalas \\ University, Limau Manis, Padang, Indonesia ${ }^{3,4}$
}

\begin{abstract}
The purpose of this research would like to see the effectiveness of how the opening of the reed land against the loss of nutrient elements are carried away by soil erosion, on critical land dam DTA Singkarak, studying the influence of various types of plants against the magnitude of the nutrient elements due to soil erosion in critical land DTA Singkarak and see the impact of the interaction between the way the opening of the land with the kind of crops against the magnitude of nutrient elements due to soil erosion in critical land DTA Singkarak. This research was carried out from March to July 2010 in critical land Nagari Aripan and analysis of soil in Soil Chemistry Laboratory Faculty of Agriculture Andalas University. This research in the form of Split Plot Design (RPT) with the primary plot treatments (4way opening land reeds) and child compartments (3 types of plants) which consists of 3 replicates. The data were analyzed statistically ( $\mathrm{F}$ test), $\mathrm{F}>$ count table (a real different) then proceed with advanced Duncan's New Multiple Range Test (DNMRT) on a practical level of $5 \%$. The results showed that the way the opening of the land more efficiently reduce nutrient elements are carried away by soil erosion is by opening the land with the granting of mulch (R1) because with the grant of this mulch can withstand a grain-grain rain instantly fell to the ground so that the erosion is smaller and the magnitude of nutrient elements are carried away by erosion is also small.
\end{abstract}

Keywords: critical land, erosion, land clearing, nutrient.

\section{Introduction}

West Sumatera has an area of 4,229,739 Ha which mostly $( \pm 80 \%)$ consist of hills and mountainous land topography, the $20 \%$ composed of flat and wavy topography, $849,950 \mathrm{Ha}$ for farmland, and 131,155 Ha of that farmland area stay in critical condition, where 110,219 $\mathrm{Ha}$ is an area outside the forest region while the remaining, 20,396 Ha, exist within the forest region.

The area for farmland is limited due to topography factor which forces the farmers to utilize hill and mountainous land topography as a farmland. Besides that, the knowledge of farmers is limited as well, especially for planting and cultivation which is not based on soil conservation principle, and it already makes the critical land is being expanded. Moreover, the need of infrastructure construction also becomes a cause of competition in land utilization, since the fertile farmland has been used for non-agriculture sector which at the end makes farmers using the dry land in hills and mountainous topography as farmland. Furthermore, the sloping land condition affects the value of high erodibility that leads the dry land becomes vulnerable to erosion [1]. 
Erosion causes land damage with the result that critical land is expanding, where the critical land is an area that loses the fertile top layer due to erosion. That land cannot be productive for agriculture sector. Losing the top surface, the nutrient element as a nutrition for plants on that ground will be lose as well. One of them is the reed land that often experiences the drought which make it flammable and also become a source of larger forest fires.

The reed's land is a marginalized area due to its low productivity. The problem of reed land's utilization for agriculture is the bad physics characteristics and soil chemistry. The wretched feature of soil physics will affect the ground water's availability since it depends on the capability of soil for with standing water. Besides that, the clayey soil accumulation on the bottom layer causes the increasing of soil content. Meanwhile, some soil chemistry problems of reed land are low cation exchange capacity, reaction of aid soil, high aluminium saturation, low nutrient element specifically phosphate and cations that could be exchanged, such as $\mathrm{Ca}$, $\mathrm{Mg}, \mathrm{K}$.

To increase the productivity of reed land as a productive and long-lasting farmland, there are things that need to be done like repairing the soil features, especially managing the soil organic element with some mechanisms of land clearing and arranging the planting pattern that suit with local condition.

One of locations that has reed field is Singkarak Catchment Area. Lake Catchment Area is an earth crust around lake that limited by ridge which retains rainfall and channels it through rivers or surface flow and underground streams heading to lake. The Singkarak Catchment Area has a region of 75,586 $\mathrm{Ha}$, and $28,742 \mathrm{Ha}(37,53 \%)$ is critical land. Increasing the critical land at that region happens because of population growth and society's need. Besides that, this critical land is mostly dominated by reed vegetation that formed by land burning activity in the summer and shifting cultivation which reducing the forest area and increasing soil erosion at rainy season [2].

The reed in critical land at Singkarak catchment area, particularly in Nagari Aripan, Solok regency, has been widely spread as mentioned in Ekspos Wali Nagari Aripan Kecamatan X Koto Singkarak (2009). It is about 35\% of Kanagarian Aripan's region which has an area of $4,460 \mathrm{Ha}$. The land utilization includes ricefield about $12 \%$ at the bottom slope, annual plant about $18 \%$ at the middle slope, forest about $0.56 \%$ at the top and middle slope, animal husbandry about $19.7 \%$, small and medium enterprise about $9.26 \%$ and the rest is offices, residential and tourist sites. Aripan is located in the rain shadow area with the rainfall is unpredictable. Location of the research has a $35 \%$ slope.

The research of conservation farming indicates that repairing soil condition is able to improve the land productivity. For soybean plant, repairing the marginalized land condition can increase the crop yield up to $800 \mathrm{~kg} / \mathrm{Ha}$. For corn, it can be improved from $2.5 \mathrm{ton} / \mathrm{Ha}$ to 5-6 ton/Ha. Then, for watermelon in reed land can achieve $25 \mathrm{ton} / \mathrm{Ha}$. This result indicates that there is an opportunity for utilization of marginalized land to be productive farmland [3].

Soybean (Glycine max (L) Merr) is a multifunction plant because it can be used for food, woof, and material for manufacture industry. Since there is a foreign exchange economization by State, soybean becomes an important commodity. The import value for fulfilling the country's need is getting bigger year by year. There are 92.000 industrial units are using soybean in Indonesia. 39\% of them stay in Central Java, 22\% in East Java, 13\% in West Java, $8.5 \%$ in Jogjakarta and the rest exist in Sumatera and Borneo. The producer of fermented soybean is about 56 thousand units, soybean curd 28 thousand units, soy sauce 1,500 units and tauco 2,100 units [4].

Watermelon (Citrullus vulgaris, Schard) is included as an annual fruit plant which has significant position for social, economic development of society and country. The 
empowerment of watermelon cultivation has a good prospect since it is able to support the increase of farmers' income. Interest of watermelon cultivation for farmers is coming from its high economic value. The watermelon farmers at the north coast of Java who practice an ordinary cultivation receiving 1-2 times income from usahatani's cost allocation which range from 1.5 - 3.0 million rupiah/Ha [5].

Objective of the research is to study the effect of Reed's land clearing method toward amount of nutrient element due to soil erosion on critical land at Singkarak catchment area, to learn the effect of various kinds of plant toward amount of nutrient element because of soil erosion on critical land at Singkarak Catchment Area and to seek for influence of interaction between land clearing mechanism and type of plant upon amount nutrient element on critical land at Singkarak catchment area.

\section{Material And Method}

\section{1 Time and Place}

The research has been conducted from March to July 2010 in Nagari Aripan's critical land, X Koto Subdistrict. Then it was continued by soil analysis in Soil Chemistry Laboratory at Agriculture Faculty, Andalas University.

\subsection{Experimental Design}

Design that being used is Split Plot Design (RPT) in which the mechanism of reed's land clearing (R) as main plot and planting (T) as sub-plot. The analysis of variance separate plot design is conducted in order to see the effect of soil variety treatment. Meanwhile, the Duncan new multiple range test $(D N M R T)$ is used to see the difference between those treatments.

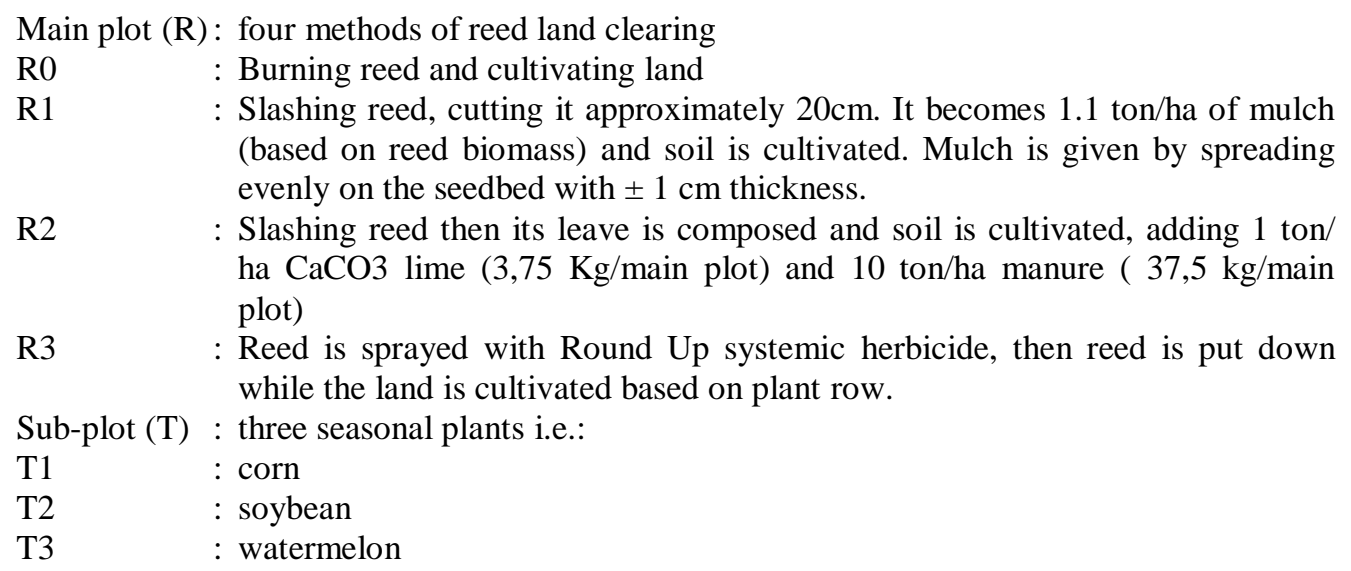

Therefore, there are 12 treatment combinations as showed through the table above. The main plot with a size $2.5 \mathrm{~m} \times 16.5 \mathrm{~m}$ and the distance between those main plots is $0.5 \mathrm{~m}$. While the sub-plot with a size $2 \mathrm{~m}$ x $5 \mathrm{~m}$ and the distance between sub-plots is $0.5 \mathrm{~m}$. Each combination is repeated 3 times until number of sample to be taken is 4 × $3 \times 3=36$ sample. The difference due to treatment will be analyzed with variance analysis in accordance to plot 
experimental design which is separated $4 \times 3$. It will be utilized and for those which have significant effect will receive further test with DNMRT.

\subsection{Research Implementation}

\subsubsection{Land preparation and the making of plot experimentation}

Reed land that has been choosen is confined (plotted) with plastic rope based on size and number of plot experimentation. The plot of land clearing method (R) is done randomly. After making the plot, land is cleared in accordance to land clearing treatment that has been appointed, and it is made to be the main plot (each main plot has a size of $2.5 \mathrm{~m} \mathrm{x} 16.5 \mathrm{~m}$ ); the distance between main plots is $0.5 \mathrm{~m}$. Finishing land clearing, then planting according to the type of plant $(\mathrm{T})$ that has been designed and made as sub-plot with a size $2 \mathrm{~m}$ x $5 \mathrm{~m}$. Distance between each sub-plot is $0.5 \mathrm{~m}$. Putting each sub-plot within main plot has been done randomly. Each sub-plot is made erosion plot with size of $1 \mathrm{~m} \times 2.5 \mathrm{~m}$, the edge of erosion plot is confined with plastic carpet which has $40 \mathrm{~cm}$ width $(20 \mathrm{~cm}$ is planted in the ground and $20 \mathrm{~cm}$ appear on the ground surface). On the bottom, there is a tank of water flow in form of guttering with a size of $150 \times 20 \times 25 \mathrm{~cm}$, at the lowest part, there is a hole to channel the surface's water flow to plastic tank.

\subsubsection{Compost production}

Reed which has been trimmed, then being chopped into pieces using machine. After that, reed will be mixed with manure according to the need. It is inserted into black plastic bag and then closed. Compost is located in roofed room in order to avoid rain and sunshine; then the compost material is incubated for one month.

\subsubsection{Soil sampling}

Initial Soil sample was being taken before experiment started. It was taken from some sites in experimentation location, then it is composited for the need of characteristic of soil chemistry analysis. The analysis of soil sample has been done in Soil Science Department Laboratory, Andalas University.

The soil sample for final analysis was taken from soil eroded which accommodated in plastic bag at each rainfall event within every single experimental plot. These soil eroded, then, is composited for the need of nutrient element's $(\mathrm{N}, \mathrm{P}, \mathrm{K}, \mathrm{Ca}, \mathrm{Mg})$ amount analysis and soil organic matter.

\subsubsection{Planting corn}

Corn planting is done with drill system; plant row is made to be parallel with the direction of contour line. The planting distance within a row is $40 \mathrm{~cm}$ and for the distance between rows is $40 \mathrm{~cm}$. Planting hole is made using a wood with $\pm 4 \mathrm{~cm}$ diameter which is sharpened at its point. This hole is created with $3-5 \mathrm{~cm}$ depth. Before planting process, corn seed is submerged for one hour and then these seed is inserted into the hole (each hole contains 3 corn seed) and covered with the soil. The variety that is used is Supermanis variety. 


\section{a. Stitching}

Stitching is only be done if there is a plant which does not grow or die after two weeks of age. The aim of stitching is to avoid decreasing population due to the died plant which affect the data obtained. If there are three corn plants grow in one hole, one plant has to be cut carefully and let the others grow.

\section{b. Fertilization}

Fertilizer that applied is Phoska NPK fertilizer $\left(15 \% \mathrm{~N}, 15 \% \mathrm{P}_{2} \mathrm{O}_{5}, 15 \% \mathrm{~K}_{2} \mathrm{O}\right.$ dan $10 \%$ $\mathrm{S})$ as the basic one at planting process, with drill system. Then, urea is given twice, the amount of urea for first fertilization is $300 \mathrm{~kg} / \mathrm{ha}$ (300 g/sub-plot) when the plant is 15 days of age and $150 \mathrm{~kg} / \mathrm{ha}$ (150 g/sub-plot) for second fertilization when the plant is 35 days of age. Urea is given by the array between plants.

\section{c. Cultivation}

Cultivation is done by watering, piling up, weeding and pest and disease control. Watering is done by using a hose that aims to keep soil water availability for plant. Watering is done once a day if there is no rain. Piling is done by piling up the stem base with soil once it is fertilized, this aim to facilitate the nutrient absorption by plant root. Piling up is done when the plant is 15-21 days of age. Weeding is conducted by pulling up the weeds, so the soil aggregate will not be damaged. The purpose of weeding is to keep the healthy condition of plant so it is able to grow and become productive significantly, fungicides that used is Rhidomil 35 SP. Fungisida is given when the plant damage such as leaves begin to rot and to have brown spot. The fungicide is given by spraying it to all parts of that plant.

\section{d. Harvest}

Harvesting can be done after the plant is 72 HST of age ( $80 \%$ of population have fulfilled the harvest criteria) which means it --- has become yellow, the seed is quite hard and shiny, if that seed is pressed with the thumb it will not leave any mark.

\subsubsection{Soybean}

\section{a. Planting}

Soybean planting is done with drill system, the seed is planted within $3 \mathrm{~cm}$ depth and backfilled with fine soil and reed as mulch. The distance between soybean plants is $40 \mathrm{x} 20$ $\mathrm{cm}$. The number of seed within each hole is about $2-3$ seeds. Similar to the corn plant, before planting the seed is submerged for one hour. The variety of this soybean is Otau variety.

\section{b. Stitching}

The plant for stitching is planted simultaneously with the time of planting; it has purpose to replace the plant that does not grow. If more than 3 plants growing in one hole, so the three plants will be left to grow while the others being cut. It aims to give the better result of soybean plant. 


\section{c. Fertilization}

Fertilizer that applied is Phoska NPK fertilizer $\left(15 \% \mathrm{~N}, 15 \% \mathrm{P}_{2} \mathrm{O}_{5}, 15 \% \mathrm{~K}_{2} \mathrm{O}\right.$ dan $10 \%$ $\mathrm{S})$ as the basic one at planting process, it is given through drill system. The first fertilization is by giving Urea fertilizer (45-0-0) with $150 \mathrm{~kg} / \mathrm{ha}(150 \mathrm{~g} / \mathrm{sub}-\mathrm{plot})$ as recommendation for the plant with 15 days of age. Fertilization is done by inserting fertilizer into $3 \mathrm{~cm}$ depth of array, and its distance from the plant is about $5 \mathrm{~cm}$. After inserting the fertilizer, array is backfilled with soil. The second fertilization will be done when the plant is 35 days of age and owns 100 $\mathrm{kg} / \mathrm{ha}(100 \mathrm{~g} / \mathrm{sub}-\mathrm{plot})$.

\section{d. Cultivation}

Cultivation is done by watering, weeding, tilling and pest and disease control. Watering is done once a day, at the morning or afternoon if there is no rain in one week. Watering aims to maintain soil moisture. Weeding is done when the growth of weed is relatively small. The first weeding is done when the plant is $2-4$ weeks of age. Weeding is done simultaneously with tilling. Tilling aims to achieve the maximal quality and quantity of production. Pest and disease control have a purpose to keep the healthy condition of plant in order it can grow and have a good production, insecticide that applied is Decis. Insecticide will be sprayed when the plant had a pest like the brown spot on soybean leaves. Insecticide is given by spraying it to all parts of plant.

\section{e. Harvest}

Soybean harvesting will be done after reaching its ripeness which is 90 days of age. It is indicated by leaves that turn to be yellow and then fall, the color changing of fruit from green to brownish-yellow with some cracks; the stem becomes yellow with slightly brown and also turns to be bare. Harvesting is done by cutting $1 \mathrm{~cm}$ of the soybean stem above soil surface; then the stem is separated with pods.

\subsubsection{Watermelon plant}

\section{a. Planting}

Watermelon seed is sown in the seedbed before the planting process. Process of raising seedling has some purposes: saving the number of seed, facilitating seed's maintenance, choosing the good seed and helping it in order not to be withered. After 3-5 days, the seed will germinate, and watermelon seed can be moved to the land that has been provided. There are one or two watermelon seed in a planting hole. One day before the watermelon is planted in the land, the planting hole has been given a basic fertilizer of NPK Phoska. The fertilization mechanism is by mixing the fertilizer with soil in the planting hole. The variety for watermelon that is utilized is New dragon.

\section{b. Fertilization}

The watermelon plant is fertilized with NPK Phoska $\left(15 \% \mathrm{~N}, 15 \% \mathrm{P}_{2} \mathrm{O}_{5}, 15 \% \mathrm{~K}_{2} \mathrm{O}, 10 \%\right.$ $\mathrm{S})$ as a basic fertilizer. It is given by mixing the land which has been prepared as a planting hole. The first fertilization will be done when the plant has grown about 1 meter length. The 
fertilizer that is used is urea (45-0-0) with recommendation of $200 \mathrm{~kg} / \mathrm{ha}(200 \mathrm{~g} / \mathrm{sub}$-plot or 10 $\mathrm{g} / \mathrm{plant}$ ). It is given through circular way. The second fertilization is done when the plant produces fruit as big as chicken egg. The fertilizer that is used is urea (45-0-0) with recommendation $150 \mathrm{~kg} / \mathrm{ha}(150 \mathrm{~g} / \mathrm{sub}-\mathrm{plot})$. It is given in similar way with the first fertilization.

\section{c. Cultivation}

Cultivation is done by watering, weeding and piling up. Watering is done at the early stage of growth for 10-15 days. Weeding and piling up has to be done carefully since the root is quite shallow. Weeding is done in 3-4 times during the growing season.

\section{d. Harvest}

Watermelon can be harvested after \pm 75 of planting. The characteristics of watermelon that can be harvested are: by hitting the watermelon with finger/hand and listening to the sound of fruit. The "heavy" sound indicate that the fruit is ripe while the "light" sound show that it is unripe. The other way to see whether the watermelon can be harvested or not is by looking at fruit stalk which has dried or changed into brown color, besides the rind within the soil changed its color from white to yellowish.

\section{Observation}

\section{Soil Analysis in the Laboratory}

The soil analysis that being conducted covered the initial soil analysis and final soil analysis: 1) N-total analysis with Kjeldahl method, 2) P-available is determined by Bray II method, 3) The amount of $\mathrm{K}, \mathrm{Ca}$ and $\mathrm{Mg}$ that can be exchanged with ammonium acetate $\mathrm{pH} 7$ through a washing method, and 4) The measurement of C-organic with Walkley and Black method.

\section{Observation in the field}

\section{a. Observation of Rainfall}

The data of rainfall observation that is used is the data from Climatology Station of Aripan Tropical Fruit Research Institute in Solok Regency.

\section{b. The amount of soil erosion for each rainfall event}

The amount of soil erosion is measured based on the amount of soil being stored in plastic bag during rainfall event. The mechanism of eroded soil's measurement is by collecting the soil in plastic bag for each rainfall event then weighing it. The nutrient element which is brought is being analyzed. 


\section{c. Observation of crop production}

$>$ Corn

At the harvest time, the wet cobs are counted and weighed, then converted into $\mathrm{Ha}$ in order to get the weight of cob per Ha.

$>$ Soybean

After soybean harvesting, pod is separated with soybean seed. Each seed within a plot is weighed in dry condition; then it is converted into $\mathrm{Ha}$ in order to get the weight of seed per Ha.

$>$ Watermelon plant

After watermelon harvesting, the weight of fruit is calculated in wet condition; then it is converted into Ha for getting the fruit weight per Ha.

\section{Result and Discussion}

\subsection{Soil Analysis in the Laboratory}

\section{Initial soil analysis}

After the initial soil analysis has been done in laboratory, the result of analysis is obtained and presented in Table 1.

Table 1 The result of chemistry characteristic analysis before treatment

\begin{tabular}{lcc}
\hline Parameter & Value & Criteria * \\
\hline $\mathrm{pH} \mathrm{H} \mathrm{H}_{2} \mathrm{O}(1: 1)$ & 5,95 & A bit sour \\
$\mathrm{N}$-total $(\%)$ & 0,32 & Average \\
$\mathrm{P}$-available & 7,81 & Low \\
$(\mathrm{ppm})$ & & \\
$\mathrm{K}-\mathrm{dd}(\mathrm{me} / 100 \mathrm{~g})$ & 1,49 & Middle \\
$\mathrm{Ca}-\mathrm{dd}(\mathrm{me} / 100 \mathrm{~g})$ & 2,00 & Low \\
$\mathrm{Mg}-\mathrm{dd}(\mathrm{me} / 100 \mathrm{~g})$ & 4,11 & High \\
Organic matter & 2,56 & Low \\
$(\%)$ & & \\
\hline ource: Staff of Soil Research Center (1983, cit Hardjowigeno, 2003)
\end{tabular}

From the result of initial soil analysis and some soil chemistry characteristics based on Table 2, it can be seen that the research location's soil has low fertility rate which is indicated by a slightly acid of soil $\mathrm{pH}$, i.e. 5.95, low level of $\mathrm{P}$ and ca element that is $7.81 \mathrm{ppm}$ and 2.00 me/100 $\mathrm{g}$ and also the low organic matter i.e. $2.56 \%$. The land where reed has grown usually has low fertility rate that indicated with the acid of soil reaction, low nutrient element especially $\mathrm{P}$ and $\mathrm{Ca}$ and low organic matter.

Organic material has important role toward the soil fertility rate, because organic matter is able to repair the physical, chemistry, and biology characteristics of soil. The amount of organic matter is influenced by depth, climate, drainage and land cultivation. Looking at its role, the organic matter of soil needs to be maintained through a good management [6] 
[7] stated that the organic material generally found in the land surface. The amount is not big, it is only about 3-5\%, but the effects of organic matter toward soil characteristics and plant growth are: 1) as granularity that is repairing soil structure, 2) the source of nutrient element $\mathrm{N}, \mathrm{P}, \mathrm{K}$ and other micro elements, 3) adding the soil capability to retain water, 4) adding the soil capability to retain nutrient element, and 5) as a source of energy for microorganism.

\section{The result of soil analysis carried by erosion}

\section{a. Element $\mathbf{N}$ and $\mathbf{P}$ of soil carried by erosion}

The result of $\mathrm{N}$ and $\mathrm{P}$ element of soil carried by erosion in various ways of land clearing is presented in Table 2 .

Table 2. The effect of land clearing toward the amount of $\mathrm{N}$ and $\mathrm{P}$ element carried by soil erosion of the three types of plant

\begin{tabular}{crc}
\hline Land clearing & $\mathbf{N}$ & $\mathbf{P}$ \\
\hline R0 & $\ldots . . \% \ldots$ & $\ldots . \mathrm{ppm} \ldots$ \\
R1 & $0,34 \mathrm{a}$ & $13,51 \mathrm{a}$ \\
R2 & $0,27 \mathrm{~b}$ & $11,44 \mathrm{a}$ \\
R3 & $0,33 \mathrm{a}$ & $11,88 \mathrm{a}$ \\
\hline
\end{tabular}

The numbers in the right column followed by the similar small letters is not significant based on the further examination of DNMRT at $5 \%$ level

Based on the statistical analysis of land clearing mechanism's influence toward the amount of $\mathrm{N}$ element in soil, at the burning treatment (R0) it is significantly different with the treatment given mulch (R1) and the treatment in round-up (R3), and also not significantly different with the treatment given compost, lime and manure (R2). Meanwhile, the influence of land clearing mechanism toward the amount of $\mathrm{P}$ soil element is not significantly different on each treatment; it can be seen in Table II. From Table II, it can be seen the highest value of $\mathrm{N}$ and $\mathrm{P}$ exist in the burning treatment (R0), i.e. $0.34 \%$ and $13.51 \mathrm{ppm}$. It happened because of burning, and then the land is conventionally cultivated without the soil cover which is able to reduce erosion. On the other hand, the lowest value of $\mathrm{N}$ and $\mathrm{P}$ exist in the treatment given mulch, i.e. $0.27 \%$ and $11.44 \mathrm{ppm}$. The low volume of $\mathrm{N}$ and $\mathrm{P}$ element in soil carried by soil erosion on mulch treatment allegedly because the mulch is able to withstand the rain that fell to the ground. Besides that, mulch on the land surface can protect the soil and reduce water evaporation from that surface.

[7] stated that the loss of $\mathrm{N}$ from soil happens because it is utilized by plants or microorganism, and $\mathrm{N}$ element which in form of $\mathrm{NO}_{3-}$ (nitrate) is easily leached by rain. In addition, $\mathrm{N}$ element is soluble and easy to be lose due to drainage water or evaporation. [8] also added that the loss of $\mathrm{N}$ happens through 1) denitrification process, 2) carried by harvesting, 3) washed by harvesting and 4) fixated by mineral. Due to its position in the soil solution, nitrate ion is easier to be leached by water flow. The direction of leaching is heading to the layer below the root zone. Therefore it cannot be utilized by the plant. 
According to [9] some of the $\mathrm{P}$ element are absorbed by the plant through diffusion mechanism which is about $93 \%$. Meanwhile, 3\% happens through root interception and 5\% through mass flow. The loss of $\mathrm{P}$ from a particular place or land also has a close relationship with the process of surface flow and erosion that can be found in high rainfall zones. Meanwhile, [6] stated that the loss of $\mathrm{P}$ due to erosion is relatively larger than the other factors, it happens because the fine particles which own high fertility as a whole will be carried from the soil by erosion.

\section{b. K, Ca and Mg element in soil carried by erosion}

The result of nutrient element analysis $\mathrm{K}, \mathrm{Ca}$ and $\mathrm{Mg}$ of soil carried by erosion in various mechanisms of land clearing is presented in Table 3.

Table 3. The effect of land clearing mechanism toward $\mathrm{K}, \mathrm{Ca}$ and $\mathrm{Mg}$ element carried by soil erosion from three types of plant

\begin{tabular}{cccc}
\hline Land clearing & K & Ca & Mg \\
\hline R0 & $1,02 \mathrm{a}$ & me/100g.. & $3,63 \mathrm{a}$ \\
R1 & $0,65 \mathrm{~b}$ & $1,02 \mathrm{a}$ & $3,45 \mathrm{a}$ \\
R2 & $0,73 \mathrm{~b}$ & $0,91 \mathrm{a}$ & $3,62 \mathrm{a}$ \\
R3 & $0,67 \mathrm{~b}$ & $0,97 \mathrm{a}$ & $3,47 \mathrm{a}$ \\
\hline
\end{tabular}

The numbers in the right column followed by the similar small letters are not significantly different based on the further examination of DNMRT at $5 \%$ level

Based on statistically analysis of the land clearing mechanism's influence toward the amount of $\mathrm{K}$ soil element, at burning treatment (R0) is significantly different with the treatment is given mulch (R1), treatment is given compost (R2) and also treatment in round-up (R3). Meanwhile, the effect of land clearing toward the value of $\mathrm{Ca}$ and $\mathrm{Mg}$ is not significantly happened for each treatment; it can be seen in Table III.

Table III. Shows that the highest amount of $\mathrm{K}, \mathrm{Ca}$ and $\mathrm{Mg}$ element exist at the burning treatment (R0), i.e. $1,02 \mathrm{me} / 100 \mathrm{~g}, 1,02 \mathrm{me} / 100 \mathrm{~g}$, and 3,63 me/100 g. It happens because this treatment does not have the soil cover which protects soil from rainfall. Therefore the soil is easy to be crushed into fine grains which close its pore. Then, it leads to inhibition of infiltration water and increasing of runoff with the result that $\mathrm{K}, \mathrm{Ca}$ and $\mathrm{Mg}$ element of soil brought by erosion will be bigger. Meanwhile, the lowest amount of $\mathrm{K}, \mathrm{Ca}$ and $\mathrm{Mg}$ element brought by soil erosion exist at the treatment given mulch $(\mathrm{R} 1)$, i.e. $0,65 \mathrm{me} / 100 \mathrm{~g}, 0,91$ $\mathrm{me} / 100 \mathrm{~g}$ and 3,45 me/100 $\mathrm{g}$. The reed that is utilized as mulch on the soil surface is able to protect the soil and reduce the water evaporation from its surface. According to [10], the more soil is drifted, the more nutrient elements carried by runoff or drifted along with soil erosion.

[11] added that the effect of erosion would make soil particle and nutrient elements are being drifted. [12] also stated that the excessive loss of nutrient element causes the degradation of soil fertility. Therefore soil cannot utilize the sufficient and balance nutrient element to support the normal growth of the plant. As a result, the soil fertility will be low. The damage in this form occurs as the effect of organic matter's reorganization and mineral weathering, nutrient element leaching in a quick way at the hot and wet tropical climate and also the loss of nutrient element through harvesting without any effort to recover it. 


\section{c. The content of soil organic carbon}

The determination result of the content of soil organic carbon carried by erosion in various ways of land clearing is presented in Table 4.

Table 4. The effect of land clearing mechanism toward the content of soil organic carbon carried by soil erosion from three types of plant

\begin{tabular}{cc}
\hline Treatment & Soil Organic Carbon \\
\hline & $\ldots . \% \ldots$ \\
R0 & $2.30 \mathrm{c}$ \\
R1 & $2.60 \mathrm{bc}$ \\
R2 & $3.44 \mathrm{a}$ \\
R3 & $3.16 \mathrm{ab}$ \\
\hline
\end{tabular}

The numbers in the right column followed by the similar small letters are not significantly different based on further test of DNMRT at the level of $5 \%$

Based on statistically analysis, the influence of Reed's land clearing mechanism toward amount of soil organic carbon is significantly different for each land clearing mechanism. It can be seen in Table IV. The highest value of carbon organic exist in the compost treatment i.e. $3.44 \%$. The high value of soil organic carbon in compost treatment exist allegedly because of big contribution of soil organic carbon from reed compost and manure. The soil organic carbon in reed compost can repair the forming process of soil aggregation so that aggregation becomes better. Meanwhile, soil organic carbon of manure is able to interact with soil particle, microorganism and to form a good microecology environment. Therefore the soil pore can be created within soil aggregation. The burning treatment has low content of soil organic carbon i.e. $2.30 \%$ because this soil does not receive soil organic carbon support. The soil organic carbon carried by soil erosion that exists in burning soil become low due to burning process. Burning causes the increasing of soil temperature, as the result, the soil organic matter is burned as well.

[13] stated that in the cultivation of soil organic matter, the sources are coming from the application of organic fertilizer such as manure and green fertilizer or compost. The soil organic matter play a role in physical, chemical and biological which determine the soil fertilization. The chemical role takes a position in determining the cation and anion exchange capacity that has an important influence on nutrient availability.

The soil organic carbon is one of construction material for soil density. Organic matter is the residue of organic living, either plant or animal starts with the fresh one, the one in decaying process and already decayed. While the organic matter in decaying process is an action that needs the high power of energy [14].

[15] explained that the source of organic matter is plant tissues like root, shrub, grasses and low-level plant which provide organic matter in a big amount for every single year. Most of the organic matter will be carried during the harvesting. Nevertheless, there are some parts that can be the source of organic matter after decaying process, such as root, leach, and straw.

\section{Rainfall observation}

The amount of rainfall, rain intensity, and rain distribution determine the dispersion power of rain upon the soil, the amount and velocity of runoff. The amount of rainfall is the height of water on a particular area that presented in meters per unit or generally stated in 
water height millimeters (mm). Rainfall is recorded at the site of the research is $181 \mathrm{~mm}$. [12]. While [1] stated that in the wet climate area like Indonesia, the rainfall becomes the main cause of runoff and erosion.

[16] proposed that some climate factor can affect erosion, such as rain, temperature, wind, humidity and solar radiation. Among those factors, rain becomes the most significant one. The result of Utomo's research indicates that the important characteristics of rain are rainfall, intensity, and distribution. Those three characteristics work together for determining the rain capability to dissolve soil grains and also the amount and velocity of runoff. The capability of rain causing erosion is called erosivity, while erodibility stands for the power of soil to be eroded.

According to [1], the influence of rain's amount and intensity on erosion is different from each other. A large amount of rain does not necessarily create erosion if the intensity is low. Similarly, the high intensity of rain does not necessarily make erosion if the amount of rain is little because there is not enough water to drift the soil. In reverse, if the amount of water is large and intensity is high, it can produce severe erosion. [12] added that the high rainfall for a long period of time would cause a large amount of eroded soil and little amount of rain in short time will create a small erosion.

\section{Conclusion and Suggestion}

1. The land clearing mechanism that can reduce the amount of nutrient element carried by erosion is

through mulch application (R1), because it can withstand the rain which fall to the land, as the result, the erosion will be smaller, and nutrient element carried by erosion become small as well.

2. There is no interaction between land clearing mechanism and type of plant toward the amount of nutrient element carried by soil erosion on critical land at Singkarak Catchment Area.

\section{Acknowledgment}

The auhtors acknowledgment the suport of Indonesian Ministry for Research, Technology and Higher Degree of Education for the Funding. and We thank to Andalas University Research and Community Services Institue for the supporting of administration of this study.

\section{References}

[1]. Rusman. B, Konservasi Tanah dan Air, Faculty of Agriculture Andalas University, pp.184, 1999.

[2]. Aisyah. S. (2009). Homepage DAS Danau Singkarak Kritis. Era Baru News, Senin 31 Agustus 2009. [Online]. Available : http : // era baru. Net / IPTEK / 80-bumi-lingkungan / 4361-das-danau-singkarak-kritis..

[3]. Zaini. Z, and Lamid. Z, "Alternatif Teknologi Budidaya Tanaman Pangan Pada Lahan Alang-alang. Dalam PPT (ed). Pemanfaatan Lahan Alang-alang Untuk Usahatani Berkelanjutan”, Pros. Seminar Lahan Alang-alang, Bogor, 1 Desember 1992.

[4]. January 2008] Antara website [Online]. Available: Antara news.com. Impor Kedelai Meningkat.htm., 21:28 
[5]. Rukmana. R, "Teknik Pengelolaan Lahan Berbukit dan Kritis”, Kanisius Publisher, Yogyakarta. Pp.40, 1995.

[6]. Hakim. N, Nyakpa. M. Y, Lubis. A. M, Nugroho. S. G, Diha. M. A, Hong. G. B, Bailey. H.H. Dasar-dasar Ilmu Tanah, Lampung University, pp.488, 1986.

[7]. Hardjowigeno. S, Ilmu Tanah, Akademika Pressindo Publisher, Jakarta, pp.286, 2003.

[8]. Ahmad. F, Arifinta, and Ridwan. M, "Masalah Lahan Kering di Sumatera Barat Dalam Jurnal Permasalahan dan Pengelolaan Air Tanah di Lahan Kering”, Research Center of Andalas University, Padang, pp.133, 1991.

[9]. Winarso.S. 2005. Kesuburan Tanah dasar Kesehatan dan Kualitas tanah. Penerbit Gava Media Yogyakarta pp 270

[10]. Bachtiar, E. 1987. Pengaruh Beberapa Jenis Kacang-kacangan yang Ditanam di antara Jalur Penyangga Rumput Terhadap Besarnya Erosi. [Skripsi] Jurusan Tanah Fakultas Pertanian Universitas Andalas. Padang. 66 hal

[9]. Soepardi. G, Sifat dan Ciri Tanah, Institut Pertanian Bogor, Bogor, pp.591, 1983.

[11] Arsyad. S, Konservasi Tanah dan Air, IPB Presss, Bogor, pp.290, 2006.

[12]. Utomo,W.H. 1989. Konservasi Tanah di Indonesia: suatu Rekaman dan Analisa. Rajawali Press. Jakarta

[13] Hanafiah. K. A, Dasar-Dasar Ilmu Tanah, Jakarta, Raja Grafindo Persada, pp.360, 2005 [14] Syarief. S, Fisika Tanah dasar, Serial Publikasi Ilmu-Ilmu Tanah. Faculty of Agriculture Universitas Padjajaran, Bandung, pp.157, 1980.

[15] Soegiman, Ilmu Tanah, Terjemahan dari H.O. Buckman dan N. C. Brady, The nature and properties of soil, Soil Sciences Department Faculty of Agriculture, IPB, Bogor, pp.591, 1982.

[16] Kalie. M. B, Bertanam Semangka, Penebar Swadaya, Jakarta, pp.51 pages, 2004. 